a Universidade Federal do Ceará, Departamento de Química Orgânica e Inorgânica, CEP 60020-181, Fortaleza-CE, Brazil.

b Instituto Federal de Educação, Ciência e Tecnologia do Ceará, Mestrado Acadêmico em Ensino de Ciências e Matemática, Campus de Fortaleza, Av. Treze de Maio 2081, Benfica, CEP: 60040-215, FortalezaCE, Brazil.

c Universidade da Integração Internacional da Lusofonia Afro-Brasileira, Instituto de Ciências Exatas e da Natureza, Curso de Licenciatura em Química, CEP 62785-000, Acarape-CE, Brazil.

d Instituto Federal de Educação, Ciência e Tecnologia do Rio Grande do Norte, Departamento de Química, CEP 59700-000 Apodi-RN, Brazil.

e Universidade da Integração Internacional da Lusofonia Afro-Brasileira, Instituto de Engenharias e Desenvolvimento Sustentável, CEP 62785-000, Acarape-CE, Brazil.

f Universidade da Integração Internacional da Lusofonia Afro-Brasileira, Instituto de Engenharias e Desenvolvimento Sustentável, Mestrado Acadêmico em Sociobiodiversidades e Tecnologias Sustentáveis, CEP 62785-000, Acarape-CE Brazil.

*E-mail: luthi2011@ gmail.com

Recebido em: 10 de Outubro de 2020

Aceito em: 31 de Março de 2021

Publicado online: 22 de Setembro de 202

\section{Preparation, Characterization, and Enantioselectivity of Polyacrylate Microcapsules Entrapping Ananas comosus Extract}

\author{
Preparação, Caracterização e Enantioselectividade de Microcápsulas de \\ Poliacrilato Entregando Extrato de Ananas comosus
}

\begin{abstract}
Antônio Luthierre Gama Cavalcante, ${ }^{a, *}$ Christian Gama Cavalcante, ${ }^{b}$ Regilany Paulo Colares, ${ }^{c}$ Daniele Alves Ferreira, ${ }^{c}$ Francisco Felipe Maia da Silva, ${ }^{d}$ EmersonYvay Almeida de Sousa, ${ }^{a}$ José Erick da Silva Souza, ${ }^{e}$ Rodolpho Ramilton de Castro Monteiro, e André Luiz Barros de Oliveira, José Cleiton Sousa dos Santos, ${ }^{\circledR 0}$ Aluísio Marques da Fonseca
\end{abstract}

\begin{abstract}
Biocatalysts are complex compounds of an enzymatic nature that can catalyze various chemical processes through diverse interactions. They are found in microorganisms, plants, and animals, and they have an essential role in processes related to green chemistry and sustainability. This research aimed to analyze pineapple peels (Ananas comosus L.) as a catalyst in the esterification reaction of rac-butan-2-ol, using acetic anhydride and ethyl acetate as acetylating agents. In order to do so, the methods used were divided into five stages: (i) Collection of pineapple cases; (ii). Immobilization of enzymes; (iii) Bioesterification reactions via enzyme; (iv) Elucidation of the data collected by GC-MS (Gas Chromatography coupled to Mass Spectrometry); and (v) Factorial Planning (execution of 4 steps again, but varying some factors determining the reaction in search of the best rational option). After statistical treatment, using different acetylating agents, two products were used: acetylated 2-butanol, with 74\% maximum conversion; and 4-hydroxy-4-methyl-pentan-2-one, obtaining $86 \%$. It should be noticed that the $74 \%$ yield of maximum conversion of rac-butan-2-ol to 2-acetoxybutane was used using Factor Planning $2^{3}$. It was concluded, then, that the immobilized enzymes of pineapple peels were efficient in the analysis of bioesterification and that these are sustainable alternatives for synthetic organic chemistry, seeing that it benefits from the inherent potential of natural sources.
\end{abstract}

Keywords: Pineapple peel; bioesterification; sustainability.

\section{Introduction}

The biocatalysts have great biotechnological potential, mainly for application in the industrial sector, ${ }^{1-5}$ as an agent for obtaining drugs, cosmetics, fuels, fungicides, and for possessing great synthetic importance to produce chiral key intermediates of pharmacological and agrochemical interest. ${ }^{6-14}$ In this context, many researchers in recent years have used plant materials as natural catalysts. ${ }^{15-18}$

The type of fundamental catalysis performed by the vegetable sources is known as biocatalysis. It covers the processes of a conversion of a substrate into a limited number of enzymatic steps. ${ }^{19-22}$ Furthermore, the enzymes from vegetables act as specific and chiral catalysts due to the high versatility in performing various organic reactions, such as Diels-Alder reactions, COPE rearrangement, sigmatropic reactions [3.3], Claisen rearrangement, among others. ${ }^{23}$ These biocatalytic results are usually safe. They may occur under mild temperature conditions with $\mathrm{pH}$ near neutral. They were, thus, minimizing problems of isomerization, racemization, and epimerization of stereogenic centres, which are frequent when using conventional catalysts. ${ }^{24,25}$

However, the application of enzymes and cells in industrial interest reactions presents an impasse regarding the stability, activity, and selectivity of these structures ${ }^{26,27}$ These problems must be overcome by immobilizing these structures. In this sense, the immobilization strategies provide some improvements to the enzymes/cells, such as greater control of the products, less reaction time, reduction of the reaction time, and improvement of the operational stability of the enzyme/cell. ${ }^{26-29}$ Although immobilization strategies can promote such improvements, it indicates that the adopted methodology follows the enzyme/cell's biochemical properties, the physical-chemical properties of the support, and its purpose using this derivative. ${ }^{27,30}$ 
Among the enzyme/cell immobilization techniques used, entrapment is one of the most cost-effective, quick, and relatively easy processes. ${ }^{31,32}$ This method confines the enzyme/cell within a given space in a polymeric matrix, with no significant impact on the morphology of the immobilized structure. ${ }^{32}$ In a polymeric matrix, polyacrylamide is a support candidate for immobilization because its biocompatible, non-toxic, inert material has a stable physical state, porosity, excellent chemical stability, and it is commercially available..$^{32-35}$

Herein, the material studied to perform the biocatalytic processes was pineapple peel (Ananas comosus) immobilized into polyacrylamide spheres by entrapment. The pineapple is a bromelain source, justified by its broad commercialization and the considerable volume of residues resulting from the industrialization of the fruit. ${ }^{35}$ Rogério et al.${ }^{35}$ estimate that in the processing of pineapple, of the whole fruits, after pressing $75-85 \%$ results in juice, and $15-25 \%$ is the process's residue, which justifies the use of biomass to add value. Previous results with other enzymatic fruit sources using intact cells have already proven that several biocatalytic reactions can be performed with organic compounds, with good yields and high enantiomeric excess

To optimize and verify, quantitatively and qualitatively, the reaction conditions that result in a better yield, experimental planning was performed based on statistical simulations. Many researchers have used this resource to minimize costs and time consumption. ${ }^{3,36}$ In this sense, the Design of Experiments (DoE) allows the optimization and verification of the main variables that influence chemical experiments. ${ }^{36}$

This work aims to use Ananas comosus extract, immobilized into polyacrylamide spheres, for the enantioselective esterification of rac-butan-2-ol. To the best of our knowledge, the present study is the first report of a successful immobilization of pineapple into polyacrylamide spheres matrix and its use on the enantioselective esterification of rac-butan-2-ol. Therefore, this study intends to present a new, economical, and environmentally acceptable way to obtain the pure enantiomer of rac-butan2-ol, via biocatalysts from pineapple residues trapped in polyacrylamide spheres. Thus, GC-FID was used to verify the enantiomeric excess (e.e.) obtained. Besides that, through factor planning, the optimization of reaction parameters was carried out in order to specify the conditions that would guarantee the best possible yield within the studied conditions; factors that significantly influence the yields of the experiments were evaluated, such as amounts of biocatalyst, acetic anhydrous, and rac-butan-2-ol.

\section{Experimental Section}

\subsection{Materials}

The peels used in this experiment were obtained from four specimens, which were purchased locally. The hydrogel beads were those of the brand XYXIANGXUN, with 2-3 $\mathrm{mm}$ in diameter. Potassium phosphate monobasic $\left(\mathrm{KH}_{2} \mathrm{PO}_{4}\right)$, sodium hydroxide $(\mathrm{NaOH})$, ethanol, ethyl acetate, $n$-propanol, methanol, acetone, hexane, phenolphthalein, brilliant blue Coomassie G-250, phosphoric acid, sodium dodecyl sulfate, mercaptoethanol, and sodium polyacrylate were acquired in its analytical grade PA form. Bovine albumin (BSA), Triton X100, filter paper for rapid filtration (qualitative $80 \mathrm{~g}$ ), and MiniProtein cell (Biorad) were used in their commercial form. The sodium hypochlorite $(\mathrm{NaClO})$ employed was the commercial product at $3 \%$, and the potassium bromide $(\mathrm{KBr})$ was of spectroscopic grade. All the other reagents were purchased from Sigma-Aldrich Co (Saint Louis, MO, USA).

\subsection{Collection and identification of botanical material}

\subsubsection{Taxonomic identification}

The pineapple peel samples were acquired in the Baturité massif region, more precisely in the municipalities of Acarape and Redenção, in the state of Ceará, Brazil, with the following geographical coordinates: $04^{\circ} 13^{\prime \prime} 35^{\prime} \mathrm{S}$ $38^{\circ} 42^{\prime \prime} 27^{\prime} \mathrm{W}$.

\subsubsection{Initial treatment of the material}

The pineapple hulls (Ananas comosus) were washed in running water, detergent, and subsequently rinsed off with distilled water and chopped into cubes of $\pm 1.5 \mathrm{~cm}$ of edge. The perforated shells were immersed in a solution of 280 $\mathrm{mL}$ of sodium hypochlorite ( $\mathrm{NaClO} 3 \%)$, and $220 \mathrm{~mL}$ of distilled water for $15 \mathrm{~min}$. After a new rinse with distilled water, the shells were subjected to drying in a greenhouse at $30 \pm 2{ }^{\circ} \mathrm{C}$ for 4 hours, in aseptic conditions ${ }^{40}$.

\subsection{A previous study of the chemical composition of the extract}

For an earlier phytochemical analysis, ${ }^{37}$ a part of the shells' material $(5 \mathrm{~g})$ was subjected to a partition with $20 \mathrm{~mL}$ of ethyl acetate. The process was followed by agitation, which was repeated three more times. Subsequently, the vacuum rotated to eliminate the solvent. The extracts were analyzed in gaseous chromatography coupled to the mass spectrum (GC-MS).

\subsection{Determination of protein content}

The determination of protein used was the "Lowry methodology," modified by Hartree (1972). ${ }^{38}$ According to Hartree (1972), it is necessary to prepare the following reagents: Solution A: $50.0 \mathrm{~g}$ of $\mathrm{Na}_{2} \mathrm{CO}_{3}$ dissolved in $250.0 \mathrm{~mL}$ of $1.0 \mathrm{M} \mathrm{NaOH}$, followed by the addition of $1.0 \mathrm{~g}$ of sodium and potassium double tartrate and dissolution in $500.0 \mathrm{~mL}$ of distilled water. Solution B: $1.0 \mathrm{~g}$ of double sodium and potassium tartrate and $0.5 \mathrm{~g}$ of $\mathrm{CuSO}_{4} \cdot 5 \mathrm{H}_{2} \mathrm{O}$ dissolved in $45.0 \mathrm{~mL}$ of water, followed by $5.0 \mathrm{~mL}$ of $\mathrm{NaOH}$ 
1.0 M. Solution C: $0.5 \mathrm{~mL}$ of the Folin-Ciocalteau reagent (molybdate, tungstate, and phosphoric acid) $2.0 \mathrm{M}$ diluted in $7.5 \mathrm{~mL}$ of water. This solution should be prepared daily, and its concentration must be between 0.15 and $0.18 \mathrm{M}$. The procedure was as follows: $0.1 \mathrm{~mL}$ of the botanical material in an aqueous solution was diluted to $50 \mathrm{~mL}$ using distilled water (if necessary). The $1.0 \mathrm{~mL}$ of this sample solution was added to $0.9 \mathrm{~mL}$ of reagent $\mathrm{A}$, followed by heating at $50{ }^{\circ} \mathrm{C}$, for 10 minutes. After cooling at room temperature, $0.1 \mathrm{~mL}$ of reagent $\mathrm{B}$ was added and left at room temperature for 10 minutes. Then, $3.0 \mathrm{~mL}$ of the reagent $\mathrm{C}$ was added, followed by agitation, which soon after was put again in a "water bath" at $50{ }^{\circ} \mathrm{C}$, for another 10 minutes. It should be cooled down to room temperature and used to perform the spectrophotometer-UV reading at the wavelength of $650 \mathrm{~nm}$. A calibration curve with bovine serum albumin (BSA) was used as a standard in the measurements. The procedure was performed in triplicate, having as a reference control a test tube containing only distilled water. As a result, the presence of $\mathrm{X} \%$ of the proteins existent in the plant material was detected. ${ }^{38}$

\subsection{Hydrolysis of nitrophenyl palmitate (p-NPP)}

This methodology is based on the hydrolysis of p-nitrophenyl palmitate ( $p$-NPP) by the enzyme in an aqueous medium, and adapted from Pencreach and Baratti ${ }^{39}$. It was used in this procedure, $50 \mathrm{~mL}$ of solution A containing $4.6 \mathrm{mM} p$-NPP in n-propanol, and $250 \mathrm{~mL}$ of solution B with $0.4 \%$ Triton X 100 and $0.1 \%$ gum arabic in 100 phosphate buffer of mM sodium ( $\mathrm{pH} 7.0$ ). Thus, $0.18 \mathrm{~mL}$ of solution $\mathrm{A}$ and $1.62 \mathrm{~mL}$ of solution $\mathrm{B}$ were transferred to a cuvette. After stabilizing the temperature at $37{ }^{\circ} \mathrm{C}, 0.2 \mathrm{~mL}$ of the soluble enzyme were added. Then, the release of yellow p-nitrophenol ( $p$-NP) was monitored at $410 \mathrm{~nm}$ against an enzyme-free blank. The change in absorbance was measured every minute, up to 5 minutes. In the immobilized enzyme, $30 \mathrm{~mL}$ of the solution reacted with 5 polyacrylamide beads containing immobilized enzymes. Subsequently, $2 \mathrm{~mL}$ of the sample was collected every minute, for up to 5 minutes, and the absorbance was measured under the same conditions. Thus, the slope of the curve "absorbance versus time" was obtained. After that, the reaction rate was determined from the molar extinction coefficient under the conditions described. This value was determined by the absorbance of standard solutions of p-nitrophenol ( $p$-NP) in the reaction mixture. One unit of activity (UPNPP) was the amount of enzyme necessary to release $1 \mu \mathrm{moL}$ of $p$-NP per minute, under the conditions described.

\subsection{Immobilization of enzymes}

For the enzyme immobilization process, an adaptation of the Kalogeris methodology was adopted, ${ }^{39}$ in which $300 \mathrm{~mL}$ of the Pineapple Peel solution and $3.0 \mathrm{~g}$ of polyacrylamide were used, which, in turn, was left under constant agitation at room temperature for 2 hours until the miscibility of the materials was completed. The hydrogel beads characterization, study of hydration, immobilization, and dehydration are described in the literature. ${ }^{37}$

After the end of the polyacrylamide spheres' expansion, it was left at rest at room temperature for 20 hours. At the end of this period, the spheres' solution was subjected to filtration, and then the immobilized enzymes were obtained. After filtrations, the process of washing the fields with distilled water followed. After being removed, the areas were left to dry at the temperature of $32{ }^{\circ} \mathrm{C}$ for two days, and presented a spherical aspect. At the end of the process, the immobilized enzymes were weighed and dehydrated, as shown in Figure 1.

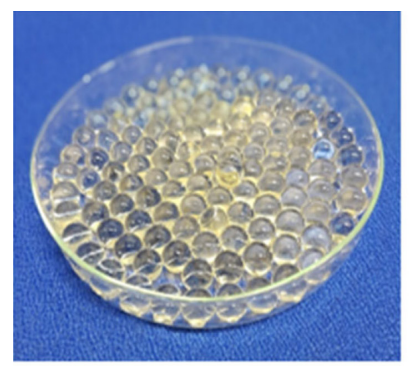

(a)

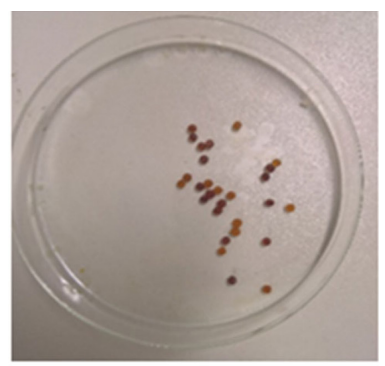

(b)
Figure 1. Polyacrylamide spheres after immobilization (a) and dehydration (b)

\subsection{Bioesterification}

The synthesis of 2-acetylate butanol by esterification was conducted in an organic medium containing hexane $(20 \mathrm{~mL})$, rac-butan-2-ol $(0.25$ or $0.50 \mathrm{~mL})$, and acetic anhydride $(2.5$ or $5.0 \mathrm{~mL})$. The reactions were carried out under mechanical agitation $(150 \mathrm{rpm})$ at $22-25^{\circ} \mathrm{C}$ for $48 \mathrm{~h}$, using bromelain immobilized into polyacrylamide spheres as a biocatalyst (6 or 12 spheres). ${ }^{40-42}$ At the end of each assay, the organic phase was dried with sodium sulfate, and then the remaining solvent was removed by reduced pressure. CG-MS determined the conversion into esters.

\subsection{Design of Experiments}

In order to find the best conditions for the esterification of rac-butan-2-ol, with acetic anhydride catalyzed by bromelain immobilized into polyacrylamide spheres, a $2^{\mathrm{k}}$ factorial design was performed. ${ }^{43}$ Thus, a $2^{3}$ factorial design was performed with spheres of immobilized biocatalyst (unit), rac-butan-2-ol (mg), and acetic anhydride $(\mathrm{mL})$ as factors varying in two levels (Table 1). In a preliminary analysis of the literature, it was noticed that the varied parameters directly impacted the percentage of conversion of the substrate into similar reactions ${ }^{44}$. Since the enzymatic load is one of the parameters with the greatest focus ${ }^{44}$. In addition, the levels were determined based on an adaptation of the bioesterification methodology proposed in that work. ${ }^{40,41,43}$ 
Table 1. Factorial design for the bioesterification

\begin{tabular}{lccc}
\hline \multirow{2}{*}{ Factor } & Code & \multicolumn{2}{c}{ Levels } \\
\cline { 3 - 4 } & & -1 & +1 \\
\hline Spheres of biocatalyst (unit) & A & 6 & 12 \\
rac-butan-2-ol (mg) & B & 0.25 & 0.50 \\
Acetic anhydride (mL) & C & 2.5 & 5.0 \\
\hline
\end{tabular}

2.9. The methodology used in rac-butan-2-ol chemical route acetylation

$300 \mathrm{mg}$ of rac-butan-2-ol, $5 \mathrm{~mL}$ of acetic anhydride, and 4-dimethylamino pyridine pinches (DMAP) were weighed and added for $2 \mathrm{~h}$. After that, $10 \mathrm{~mL}$ of copper sulfate (neutralization solution) was added. The phases were separated, and then the reaction was treated, extracting the acetylated product present in the aqueous medium ${ }^{45}$.

\subsubsection{The methodology of optical readings by a polarimeter - Polarimeter Data}

The polarimeter used to measure the observed optical rotation was of the brand CHIMIS: Automatic digital Polarimeter, model Q760M2, 220v-50w.

\subsubsection{The angle of the plane rotation of the polarized light}

The product was read by a polarimeter and had its enantiomeric excess calculated according to the literature methodology $y^{46}$. The value of the polarized light plane's rotational angle was induced by the sample (product), as read in the polarimeter. The solvent used was chloroform, using the sodium lamp $D$ with wavelength $\lambda=589 \mathrm{~nm}$, and the measurement was performed at room temperature. The concentration of the solution was calculated by the formula below, according to the specific rotational power, $[\alpha]_{D}$ :

$$
[\alpha]_{D}=\frac{[\alpha]}{c l}
$$

In which $\alpha$ is the observed rotation, " $c$ " the concentration of the solution in $\mathrm{g} / \mathrm{mL}$, and "l" the length of the tube in $\mathrm{dm}$. Given the volume of the prepared solution, the concentration was quickly determined.

\subsubsection{Calculation of optical purity (enantiomeric excess $=$ e. e.)}

The enantiomeric excess (e.e.) was defined according to the expression:

$$
\text { e.e. }=\frac{[\alpha]_{a b s}}{[\alpha]_{\max }} \times 100
$$

In which $[\alpha]$ obs is the specific rotational power of the sample, $[\alpha]$ max is the maximum specific rotational power (that of a pure enantiomer solution, according to the literature), and $R$ and $S$ are the mixture enantiomers ${ }^{47}$. The value of e.e. being positive means that the enantiomer is in excess in the sample, being negative means that it is in deficit (the enantiomer is rotating the light in the opposite direction to the example), and being null implies that the specific rotational power of the sample is invalid, i.e. the sample is a racemic mixture.

\subsection{Mass spectrometry (MS)}

The mass spectra of the methyl esters, reagents, and biocatalysis products were obtained from the HewlettPackard, HP-5971 A model, coupled to a gas-liquid chromatography, model HP-5890 A, Series II (LGC/MS), provided with a capillary column of Methyl-phenyl silicon $(25.0 \mathrm{~m} \times 0.20 \mathrm{~mm} \times 0.25 \mu \mathrm{m})$ using helium at $1.0 \mathrm{~mL} / \mathrm{min}$ as a carrier gas in split mode, operating with temperature gradients that varied depending on the chemical nature of the compounds analyzed. For the low molecular mass compounds, a slope of $10^{\circ} \mathrm{C} / \mathrm{min}\left(40-180{ }^{\circ} \mathrm{C}\right)$ and $40^{\circ} \mathrm{C} / \mathrm{min}$ $\left(180-300{ }^{\circ} \mathrm{C}\right)$ was used, and for the higher molecular mass a gradient of $10^{\circ} \mathrm{C} / \mathrm{min}\left(100-180{ }^{\circ} \mathrm{C}\right)$ and $40^{\circ} \mathrm{C} / \mathrm{min}$ (180-300 ${ }^{\circ} \mathrm{C}$ ) was used, with a gun temperature of $250{ }^{\circ} \mathrm{C}$ and detector of $280{ }^{\circ} \mathrm{C} .{ }^{37}$

\subsection{Gas chromatography coupled to flame ionization detector (GC-FID)}

The determination of enantiomeric excess (e.e.) was obtained by gas chromatography of the Thermo Electron model Trace GC Ultra, equipped with a chiral capillary column of Varian Chang-Dex CB ( $\beta$-cyclodextrin, $25.0 \mathrm{~m} \times 0.25 \mathrm{~mm} \times 0.25 \mu \mathrm{m}$ ), using helium as gas carrier with $1.0 \mathrm{~mL} / \mathrm{min}$ flow in split mode. Two temperature programs were used: $2{ }^{\circ} \mathrm{C} / \mathrm{min}\left(100-180{ }^{\circ} \mathrm{C}\right)$ and $2{ }^{\circ} \mathrm{C} / \mathrm{min}$ $\left(130-160{ }^{\circ} \mathrm{C}\right)$. The temperature of the injector and detector was $220^{\circ} \mathrm{C} .48$

\section{Results and Discussion}

\subsection{Study of phytochemical composition}

Regarding the study of the ethyl acetate extract's phytochemical composition in pineapple peel (Ananas comosus), a gas chromatography analysis coupled to the mass spectrometry (GC-MS) was performed, obtaining the following data, see Figure 2 and Table 2.

The chromatogram presented the equivalent of ten peaks, which reports the existence of several chemical classes, highlighting esters $(63.7 \%)$, aldehyde $(4.4 \%)$, alcohols $(9.6 \%)$, and acids $(12.6 \%)$. The main components were methyl ester of (Z)-9-octadecenoic acid with $26.4 \%$, and methyl ester of Methyl ester (Z)-3-octyl oxiraneoctanoic acid with $13.4 \%$, which together with the others justify its characteristic odor. In the study by Fonseca et al. ${ }^{37}$ reactions were carried out using bromelain immobilized in hydrogel spheres as a biocatalyst in esterification reactions, producing esters and derivatives methyl oleate and ethyl oleate, with 


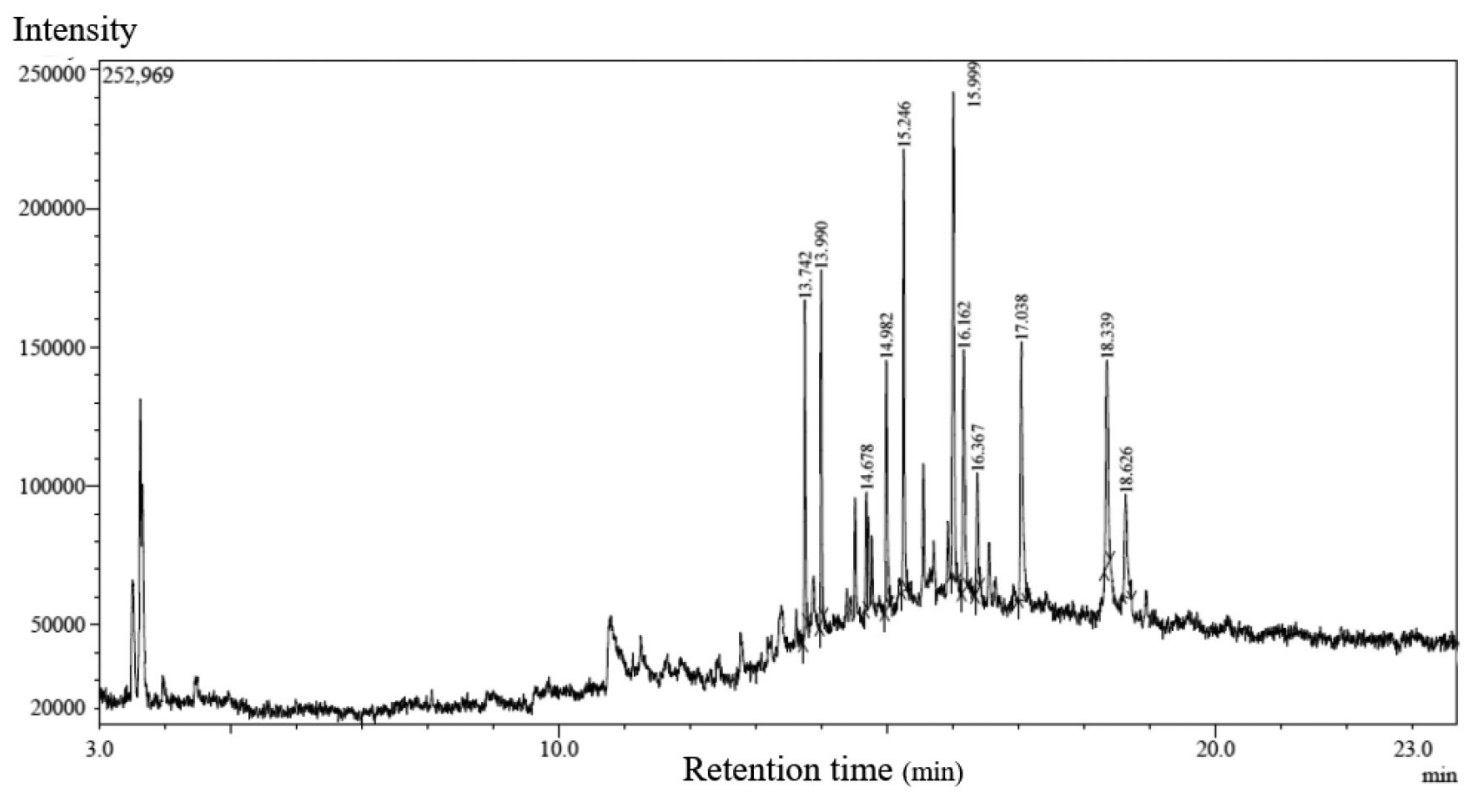

Figure 2. Chromatogram of the constituents found in pineapple peel

Table 2. Qualitative and quantitative composition of the constituents of pineapple peel by GC/MS

\begin{tabular}{|c|c|c|c|c|}
\hline Peak & Retention time (RT) & Name & $\%$ & Characterization \\
\hline 1 & 13.42 & Hexadecanoic acid methyl ester & 7.9 & RT, GC/MS, literature. \\
\hline 2 & 13.99 & Hexadecanoic acid ethyl ester & 8.0 & RT, GC/MS, literature. \\
\hline 3 & 14.68 & Oleyl alcohol & 3.8 & RT, GC/MS, literature. \\
\hline 4 & 14.98 & Isoamyl Laurate & 7.9 & RT, GC/MS, literature. \\
\hline 5 & 15.24 & Methyl ester (Z)-3-octyl oxiraneoctanoic acid & 13.4 & RT, GC/MS, literature. \\
\hline 6 & 15.99 & Methyl ester (Z) 9-Octadecenoic acid & 26.4 & RT, GC/MS, literature. \\
\hline 7 & 16.37 & (Z)-9-Hexadecenal & 4.4 & RT, GC/MS, literature. \\
\hline 8 & 17.03 & (Z)-9,10-Epoxioctadecanoic acid & 12.6 & RT, GC/MS, literature. \\
\hline 9 & 18.33 & 7-methyl-Z,Z-8,10-hexadecadien-1-ol acetate & 9.4 & RT, GC/MS, literature. \\
\hline 10 & 18.62 & Phytol & 5.8 & $\mathrm{RT}, \mathrm{GC} / \mathrm{MS}$, literature. \\
\hline
\end{tabular}

yields higher than $40 \%$ of maximum substrate conversion. Therefore, the selectivity of said enzyme in ester synthesis is noticeable.

The enantioselectivity of the enzymes present in pineapple peel was verified in a digital polarimeter, which produced $R$-(-)-2-acetoxybutane, with a $20 \%$ yield, obtaining $17.5 \mathrm{mg}$ from $100 \mathrm{mg}$ of starting material. Follow the data for the calculation of enantiomeric excess (e.e.).

\subsection{The calculation to obtain an enantiomeric excess of the acetylated material}

The optical activity value obtained in the polarimeter was $-17.78^{\circ}$. In which,

e.e. $=\frac{[\alpha]}{[\alpha]_{D}} \times 100=\frac{-17,78}{-20,0} \times 100=89 \%$ of $R$ isomer

Nine reactions based on factorial planning were performed, which varied: 1 . Several spheres were used for the reaction; 2. Quantity of the substrate; 3. Acetylating amount of the agent; and 4. Acetylating agent, keeping the organic reactional medium and temperature fixed in 72 hours. The data is shown in Table 3.

The chemoselective esterification to the correspondent of the acetyl rac-butan-2-ol, and the e.e. were determined both in a polarimeter with a value of $89 \%$ and in chiral analysis, made in GC of its acylated derivative, which presented an amount of $92 \%$ of the R enantiomer, as shown by Figure 3 .

\subsection{Immobilization parameters - Protein Concentration}

The protein content for the extract from the crushed shells solution under mechanical stirring (EXT) was $1.28 \mathrm{mg} / \mathrm{mL}$ after $24 \mathrm{~h}$ immersion. In this sense, the hypothesis raised in the literature confirmed that the increase in the contact surface generated by shredding the shells allows for a higher concentration of proteins, thus favoring extraction ${ }^{37}$. However, this protein content is leveraged in the immobilization process, considering that this process generated a protein 
Table 3. Reaction conditions of 1 - 8 factorial experimental design of type $2^{3}$ - Time and temperature remained fixed during the experiments

\begin{tabular}{cccc}
\hline Condition & Acetic anhydride $(\mathrm{mL})$ & Butan-2-ol $(\mathrm{mg})$ & Spheres of biocatalyst (unit) \\
\hline 1 & 2.5 & 0.25 & 6 \\
2 & 5.0 & 0.25 & 6 \\
3 & 2.5 & 0.50 & 6 \\
4 & 5.0 & 0.50 & 6 \\
5 & 2.5 & 0.25 & 12 \\
6 & 5.0 & 0.25 & 12 \\
7 & 2.5 & 0.50 & 12 \\
8 & 5.0 & 0.50 & 12 \\
\hline
\end{tabular}

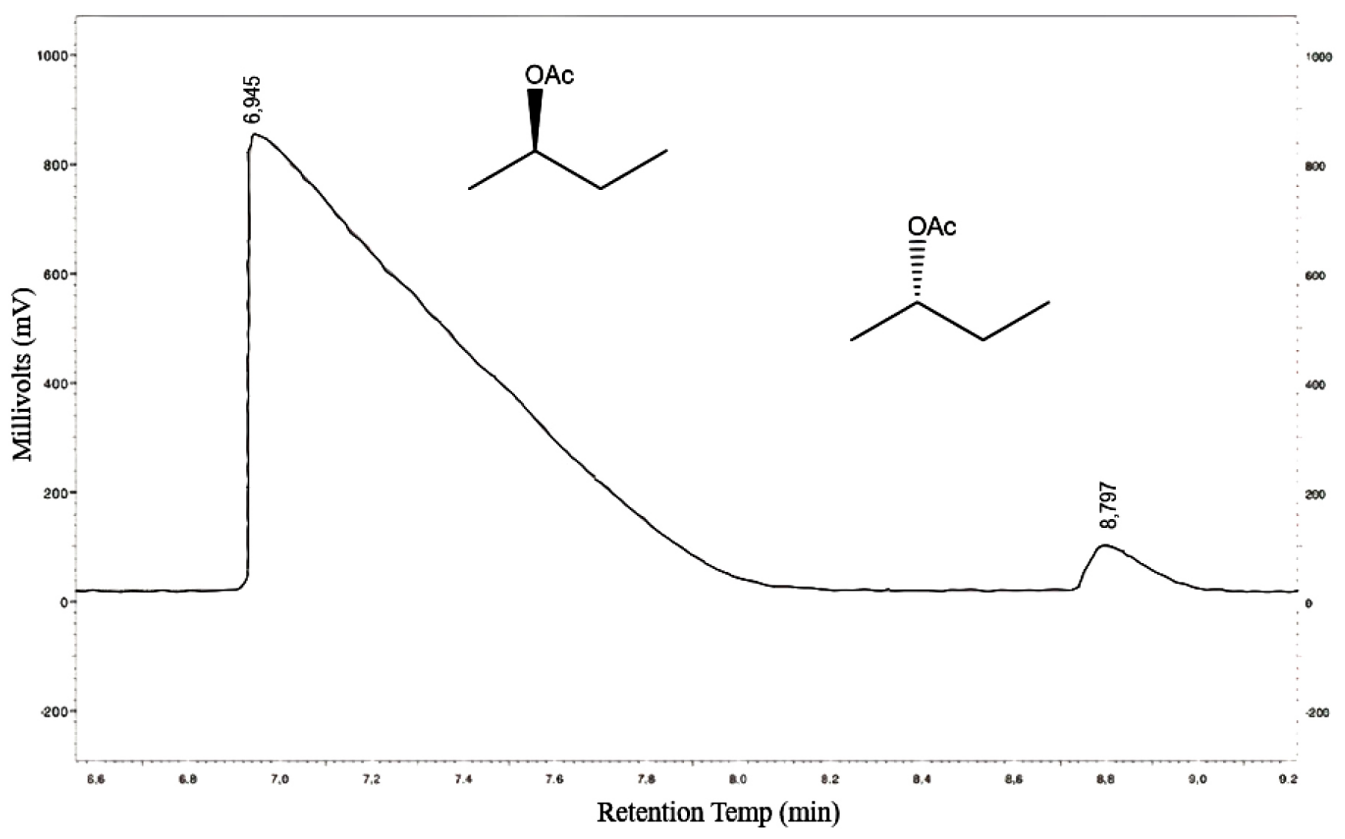

Figure 3. GC-FID (Chirasil-Dex CB) of R-(-)-butan-2-ol acylated with e.e. of $92 \%$

concentration of around $68.93 \mathrm{mg} / \mathrm{g}$ of immobilized enzymes per gram of support. In works that used only the immersion of the shells without crushing and without mechanical agitation, the results obtained for the protein content were about 5 times lower, thus making the process unfeasible ${ }^{49}$.

\subsection{Hydrolysis activity: $p$-nitrophenyl palmitate ( $p-N P P)$}

According to the analysis of the data obtained regarding the hydrolysis activity of $p$-nitrophenyl palmitate ( $p$-NPP) against the enzyme extract, it was possible to confirm the immobilization of the enzymes in the spheres ${ }^{50}$. The observed values show that mechanical agitation favored the extraction of lipases that hydrolyze this type of substrate. The elucidated immobilization yield was $28.9 \%$ in terms of proteins; however, it was only $7.85 \%$ in terms of catalytic activity. Then the extract's enzymatic activity was about $0.0126 \pm 0.0012 \mathrm{U} / \mathrm{mL}$, and the activity of the immobilized spheres was approximately $0.0228 \pm 0.0051 \mathrm{U} / \mathrm{g}$. Thus, it is noticeable that the enzymatic immobilization process is exceptionally favorable, since it improves several characteristics of the enzyme. In this case, the catalytic activity of the lipase was practically doubled. ${ }^{20,51,52}$ According to Fonseca et al. ${ }^{37}$ the increase in time, for more than 24 hours of extraction, contributes unfavorably to the immobilization yield and the enzyme's catalytic activity. Table 4 shows the data for this activity.

\subsection{Yield of the first bioesterification reactions}

In the first three bioesterification reactions described in the methodology, the reaction products and the percentage of these were verified with a GC-MS aid. It is worth mentioning that, when using acetic anhydride as an acetylating agent, acetylated, 2-butanol was obtained with a yield of $44.58 \%$. In the other two reactions, using ethyl acetate as an acetylating agent and varying only the number of spheres (12 and 6), the yields were 82.98 and $76.69 \%$, respectively of the 4-hydroxy compound it was obtained 4-methyl-pentan2-one. Table 5 organizes this data. 
Table 4. Parameters of immobilization and hydrolysis activity of $p$-NPP for $24 \mathrm{~h}$ extraction

\begin{tabular}{ccccc}
\hline Pineapple Peels & $\begin{array}{c}\text { Enzymatic Extract } \\
\text { activity }\left(\mathbf{U} \cdot \mathbf{m L}^{-1}\right)\end{array}$ & $\begin{array}{c}\text { Immobilized enzyme } \\
\text { activity }\left(\mathbf{U . g}^{-1}\right)\end{array}$ & $\begin{array}{c}\text { Yields in terms of } \\
\text { protein (\%) }\end{array}$ & $\begin{array}{c}\text { Yields in terms of } \\
\text { activity (\%) }\end{array}$ \\
\hline Extraction & $0.0126 \pm 0.0012$ & $0.0228 \pm 0.0051$ & $28,9 \%$ & $7,85 \%$ \\
\hline
\end{tabular}

Table 5. Yields of bioesterification reactions with $r a c$-2-butanol

\begin{tabular}{ccc}
\hline Product/Reaction & $\begin{array}{c}\text { \% Alcohol } \\
\text { (substrate: 2-butanol) }\end{array}$ & \% Product \\
\hline Analysis 1 & $55.42 \%$ & $44.58 \%$ (2-butanol acetylated) \\
Analysis 2 & $17.02 \%$ & $82.98 \%$ (4-hidroxi 4-metil-pentan-2-ona) \\
Analysis 3 & $23.31 \%$ & $76.69 \%$ (4-hidroxi 4-metil-pentan-2-ona) \\
\hline
\end{tabular}

Analysis 1 was carried out to identify the most formed product by identifying the acetylated butan-2-ol, which in turn aroused the interest of the collaborators, enabling the production of an experimental plan to optimize the reaction that will be presented and discussed in the subsequent topics.

A peculiar case observed with the emergence of the 4-hydroxy-4-methyl-pentan-2-one product in the $\mathrm{A} 2$, and $\mathrm{A} 3$ reactions, with yields of $83.0 \%$ and $76.7 \%$, respectively, and the following reaction conditions: substrate mass $500 \mathrm{mg}$ and $250 \mathrm{mg}$; and the acetylating agent, in this case, the ethyl acetate, with volumes of $5.0 \mathrm{~mL}$ and $2.5 \mathrm{~mL}$, which suggests that there was a secondary reaction after the biocatalysis. It is possible that calcium polyacrylate in reaction with ethyl acetate generates propanone and calcium carbonate, as shown in Scheme 2. Soon after, two moles of propanone in the organic medium in the presence of enzymes from the product. ${ }^{53-56}$

\subsection{Bioesterification}

In order to determine the optimal content of immobilized biocatalyst, acetic anhydride (mL), and rac-2-butanol (mg) for the synthesis of 2-acetylate butanol, using hexane as a solvent and bromelain immobilized into polyacrylamide as a biocatalyst, a $2^{3}$ factorial design was carried out and the results were presented in Table 6 . The highest yield

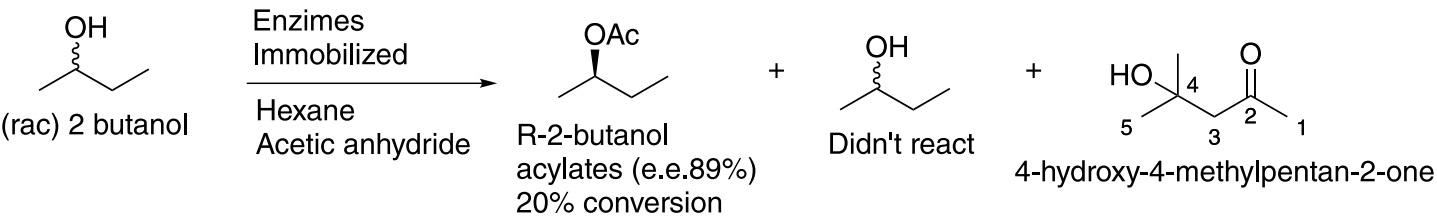

Scheme 1. 2-Butanol reaction and its by-product

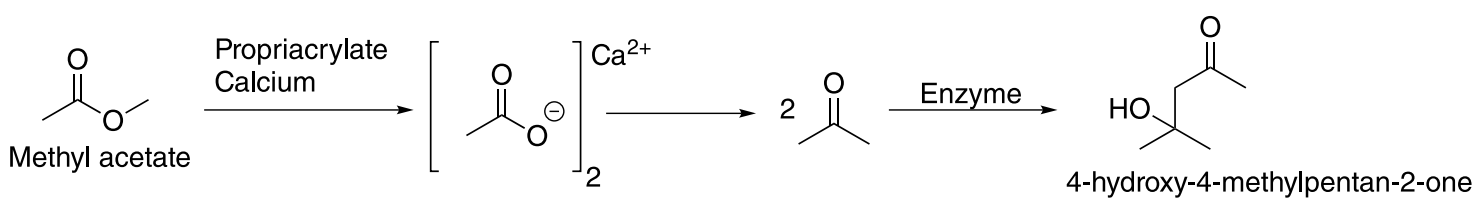

Scheme 2. Secondary reaction forming product 2

Table 6. $2^{3}$ factorial design for the bioesterification of $\mathrm{rac}$-2-butanol $(\mathrm{mg})$ with acetic anhydride $(\mathrm{mL})$ catalyzed by bromelain immobilized into polyacrylamide spheres. The reaction was performed in hexane media under mechanical agitation $(150 \times \mathrm{rpm})$ at $22-25^{\circ} \mathrm{C}$, for $48 \mathrm{~h}$. Further details are given in the Material and Methodology section

\begin{tabular}{ccccc}
\hline Assay & Acetic anhydride $(\mathbf{m L})$ & Butan-2-ol $(\mathbf{m g})$ & Spheres of biocatalyst (unit) & Yield (\%) \\
\hline $\mathbf{1}$ & 2.5 & 0.25 & 6 & $60.59 \pm 0.5$ \\
$\mathbf{2}$ & 5.0 & 0.25 & 6 & $65.20 \pm 0.4$ \\
$\mathbf{3}$ & 2.5 & 0.50 & 6 & $44.80 \pm 0.8$ \\
$\mathbf{4}$ & 5.0 & 0.50 & 6 & $58.27 \pm 0.5$ \\
$\mathbf{5}$ & 2.5 & 0.25 & 12 & $68.20 \pm 0.3$ \\
$\mathbf{6}$ & 5.0 & 0.25 & 12 & $73.51 \pm 0.3$ \\
$\mathbf{7}$ & 2.5 & 0.50 & 12 & $72.51 \pm 0.5$ \\
$\mathbf{8}$ & 5.0 & 0.50 & 12 & $73.92 \pm 0.2$ \\
\hline
\end{tabular}




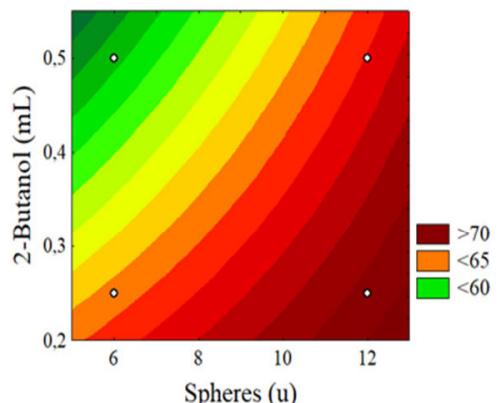

(a)

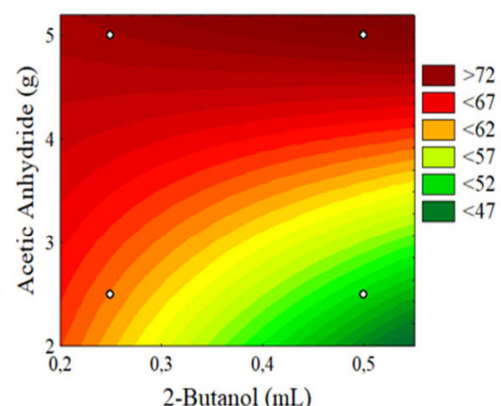

(b)

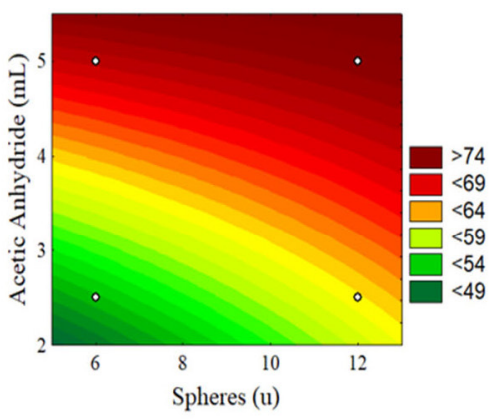

(c)

Figure 4. The number of spheres versus substrate mass (a); the number of spheres versus volume of the acetylating agent (b); the mass ratio of substrate versus volume of acetylating agent (c)

$(73.92 \pm 0.2)$ was obtained for assay $8(5.0 \mathrm{~mL}$ of acetic anhydride, $0.50 \mathrm{mg}$ of $\mathrm{rac}$-2-butanol, and 12 spheres of the biocatalyst.) A similar yield (73.51 \pm 0.3$)$ was achieved for essay 6 , but using half of the racemic mixture's content. The model fitting is checked by the determination coefficient $\left(R^{2}\right)$. The $R^{2}$ value (0.9710) implies that sample variation of up to $97 \%$ is attributed to the independent variables and can be explained by the model.

Therefore, the highest yield was achieved for the factors at their highest levels, which may suggest that higher conversion could be achieved if the volume of acetic anhydride was increased, as well as the amount of the spheres of the biocatalyst. Interestingly, similar yields were achieved for the lowest and highest butan-2-ol content; thus, for optimization purposes, the reaction could be performed using the lower content of butan-2-ol. As a matter of fact, according to Figures 4(a) and 4(c), the increase in the number of spheres of biocatalyst increases the yield, once it increases the number of active sites in the medium, thus allowing more significant contact between the biocatalyst and the substrate and favoring the formation of the complex enzyme/substrate. ${ }^{57}$

Figures 4(b) shows the reaction synergism between rac-2-butanol and acetic anhydride. When increasing the volume of the acetylating agent, there is an increase in the maximum substrate conversion. Hence, it was observed that the higher the volume of acetylating agent and the lower the mass of substrate, the better the yield of the reaction synergism, which favors the effect of the substrate and decreases the effect of the acetylating agent in the reaction.

\section{Conclusion}

Bromelain immobilized in polyacrylate spheres proved to be efficient in applying esterification when the fundamental factors are optimized. The use of factorial planning contributes to the adequacy of reaction conditions, and the reactive system is more identified, promoting a conversion percentage of $\sim 74 \%$. Determine the number of spheres with immobilized enzymes factor, which most favored a reaction for this conversion percentage to be reached. It should be noted that the analysis of factorial planning control data-enabled different readings and about interactions between the variable effects (A, B, and C). It should be noted that the limited amount of substrate, factor $\mathrm{B}$, favors the harmful reaction to the conversion of the product, and factor $\mathrm{C}$ is dependent on the interaction with factor A to enable or favor the reaction.

Stereospecificity of enzymes recover the esterification. It was justified by the phytochemical analysis of pineapple peels, which reported a percentage higher than $60 \%$ of esters in its composition. Being the methyl ester of (Z)-9octadecenoic acid or constituted by the majority, presented $26.4 \%$ of the total of compounds. The majority presence of esters gives this characteristic odor.

The polarimetric method determines an enantiomeric excess of $89 \%$ of compound $\mathrm{R}$, approximately. In a complementary manner, the gas chromatography technique coupled to the flame ionization detector (GC-FID) was used, using a chiral chromatographic column, which in turn indicates an enantiomeric excess of $92 \%$ of the compound $R$. These results showed which enantioselectivity of the enzyme, for this specific reaction, has a higher affinity for the number $\mathrm{R}$.

Due to the exposed facts, it is intended to increase or reach the maximum percentage of change using some adjustments. The differences and optimization with the support of the Taguchi Planning methodology, in addition to the production of a mathematical model, justify and verify the most significant values.

\section{Acknowledgments}

The authors would like to thank the Brazilian funding agencies: Cearense Foundation for Scientific and Technological Development Support (FUNCAP), National Council for Scientific and Technological Development (CNPq), and Coordination for the Improvement of Higher Education Personnel (CAPES) for scholarships and financial support. 


\section{References}

1. Cavalcante, F. T. T.; Neto, F. S.; Rafael de Aguiar Falcão, I.; Erick da Silva Souza, J.; de Moura Junior, L. S.; da Silva Sousa, P.; Rocha, T. G.; de Sousa, I. G.; de Lima Gomes, P. H.; de Souza, M. C. M.; dos Santos, J. C. S.; Opportunities for improving biodiesel production via lipase catalysis. Fuel 2020, 119577. [CrossRef]

2. de Souza, T. C.; de Sousa Fonseca, T.; de Sousa Silva, J.; Lima, P. J. M.; Neto, C. A. C. G.; Monteiro, R. R. C.; Rocha, M. V. P.; de Mattos, M. C.; dos Santos, J. C. S.; Gonçalves, L. R. B.; Modulation of lipase B from Candida antarctica properties via covalent immobilization on eco-friendly support for enzymatic kinetic resolution of rac-indanyl acetate. Bioprocess and Biosystems Engineering 2020, 43, 2253. [CrossRef]

3. Souza, J. E. S.; Monteiro, R. R. C.; Rocha, T. G.; Moreira, K. S.; Cavalcante, F. T. T.; de Sousa Braz, A. K.; de Souza, M. C. M.; dos Santos, J. C. S.; Sonohydrolysis using an enzymatic cocktail in the preparation of free fatty acid. 3 Biotech 2020, 10, 254. [CrossRef]

4. Lima, P. J. M.; da Silva, R. M.; Neto, C. A. C. G.; Gomes e Silva, N. C.; Souza, J. E. da S.; Nunes, Y. L.; Sousa dos Santos, J. C.; An overview on the conversion of glycerol to value-added industrial products via chemical and biochemical routes. Biotechnology and Applied Biochemistry 2021. [CrossRef]

5. Rocha, T. G.; de L. Gomes, P. H.; de Souza, M. C. M.; Monteiro, R. R. C.; dos Santos, J. C. S.; Lipase Cocktail for Optimized Biodiesel Production of Free Fatty Acids from Residual Chicken Oil. Catalysis Letters 2020, 150. [CrossRef]

6. Bezerra, R. M.; Monteiro, R. R. C.; Neto, D. M. A.; da Silva, F. F. M.; de Paula, R. C. M.; de Lemos, T. L. G.; Fechine, P. B. A.; Correa, M. A.; Bohn, F.; Gonçalves, L. R. B.; dos Santos, J. C. S.; A new heterofunctional support for enzyme immobilization: $\mathrm{PEI}$ functionalized $\mathrm{Fe} 3 \mathrm{O} 4 \mathrm{MNPs}$ activated with divinyl sulfone. Application in the immobilization of lipase from Thermomyces lanuginosus. Enzyme and Microbial Technology 2020, 138, 109560. [CrossRef]

7. Pinheiro, M. P.; Monteiro, R. R. C.; Silva, F. F. M.; Lemos, T. L. G.; Fernandez-Lafuente, R.; Gonçalves, L. R. B.; dos Santos, J. C. S.; Modulation of Lecitase properties via immobilization on differently activated Immobead-350: Stabilization and inversion of enantiospecificity. Process Biochemistry 2019, 87, 128. [CrossRef]

8. Lima, G. V.; da Silva, M. R.; de Sousa Fonseca, T.; de Lima, L. B.; de Oliveira, M. da C. F.; de Lemos, T. L. G.; Zampieri, D.; dos Santos, J. C. S.; Rios, N. S.; Gonçalves, L. R. B.; Molinari, F.; de Mattos, M. C.; Chemoenzymatic synthesis of (S)-Pindolol using lipases. Applied Catalysis A: General 2017, 546, 7. [CrossRef]

9. Fonseca, A. M. da; Cleiton Sousa dos Santos, J.; de Souza, M. C. M.; de Oliveira, M. M.; Colares, R. P.; de Lemos, T. L. G.; Braz-Filho, R.; The use of new hydrogel microcapsules in coconut juice as biocatalyst system for the reaction of quinine. Industrial Crops and Products 2020, 145, 111890. [CrossRef]

10. Cordell, G. A.; Lemos, T. L. G.; Monte, F. J. Q.; de Mattos,
M. C.; Vegetables as Chemical Reagents $\perp$. Journal of Natural Products 2007, 70, 478. [CrossRef]

11. Monteiro, R. R. C.; Lima, P. J. M.; Pinheiro, B. B.; Freire, T. M.; Dutra, L. M. U.; Fechine, P. B. A.; Gonçalves, L. R. B.; de Souza, M. C. M.; dos Santos, J. C. S.; Fernandez-Lafuente, R.; Immobilization of Lipase A from Candida antarctica onto Chitosan-Coated Magnetic Nanoparticles. International Journal of Molecular Sciences 2019, 20, 4018. [CrossRef]

12. Wessner, M.; Nowaczyk, M.; Brandenbusch, C.; Rapid identification of tailor-made aqueous two-phase systems for the extractive purification of high-value biomolecules. Journal of Molecular Liquids 2020, 314, 113655. [CrossRef]

13. Naveed, M.; Nadeem, F.; Mehmood, T.; Bilal, M.; Anwar, Z.; Amjad, F.; Protease-A Versatile and Ecofriendly Biocatalyst with Multi-Industrial Applications: An Updated Review. Catalisys Letters 2020, 151, 307. [CrossRef]

14. Sunder, A. V.; Shah, S.; Rayavarapu, P.; Wangikar, P. P.; Expanding the repertoire of nitrilases with broad substrate specificity and high substrate tolerance for biocatalytic applications. Process Biochemistry 2020, 94, 289. [CrossRef]

15. Crestani, M.; Barbieri, R. L.; Hawerroth, F. J.; Carvalho, F. I. F. de; Oliveira, A. C.; Das Américas para o Mundo: origem, domesticação e dispersão do abacaxizeiro. Ciência Rural 2010, 40, 1473. [CrossRef]

16. Yousefi, M.; Khanniri, E.; Shadnoush, M.; Khorshidian, N.; Mortazavian, A. M.; Development, characterization and in vitro antioxidant activity of chitosan-coated alginate microcapsules entrapping Viola odorata Linn. extract. International Journal of Biological Macromolecules 2020, 163, 44. [CrossRef]

17. dos Santos, M. M. O.; Gama, R. S.; Carvalho Tavares, I. M.; Santos, P. H.; Gonçalves, M. S.; Carvalho, M. S.; Barros Vilas Boas, E. V.; Oliveira, J. R.; Mendes, A. A.; Franco, M.; Application of lipase immobilized on a hydrophobic support for the synthesis of aromatic esters. Biotechnology and Applied Biochemistry 2020, 1959. [CrossRef]

18. Hauer, B.; Embracing Nature's Catalysts: A Viewpoint on the Future of Biocatalysis. ACS Catalysis 2020, 10, 8418. [CrossRef]

19. Shukla, P.; Recent advances in Applied Microbiology, Spinger: Singapore, 2017. [CrossRef]

20. Cavalcanti, E. D. C.; Aguieiras, É. C. G.; da Silva, P. R.; Duarte, J. G.; Cipolatti, E. P.; Fernandez-Lafuente, R.; da Silva, J. A. C.; Freire, D. M. G.; Improved production of biolubricants from soybean oil and different polyols via esterification reaction catalyzed by immobilized lipase from Candida rugosa. Fuel 2018, 215, 705. [CrossRef]

21. Jemli, S.; Ayadi-Zouari, D.; Hlima, H. Ben; Bejar, S.; Biocatalysts: application and engineering for industrial purposes. Critical Reviews in Biotechnology 2016, 36, 246. [CrossRef]

22. Sugappriya, M.; Sudarsanam, D.; Joseph, J.; Mir, M. A.; Selvaraj, C. Biotechnological Applications of Polyhydroxyalkanoates, $1 \mathrm{a}$. ed., Springer: Singapore, 2019. [CrossRef]

23. Faber, K.; Biotransformations in Organic Chemistry Springer: Berlin, 2011. [CrossRef]

24. Baraldi, P. T.; Corrêa, A. G.; O emprego de fermento de pão, Saccharomyces cerevisiae, na síntese de feromônios. Química Nova 2004, 27, 421. [CrossRef] 
25. Silverman, R. E.; Organic Chemistry of Enzyme-Catalyzed Reactions, 2a. ed., Elsevier: New York, 2002. [CrossRef]

26. Guldhe, A.; Singh, B.; Mutanda, T.; Permaul, K.; Bux, F.; Advances in synthesis of biodiesel via enzyme catalysis: Novel and sustainable approaches. Renewable and Sustainable Energy Reviews 2015, 41, 1447. [CrossRef]

27. Sharifi, M.; Sohrabi, M. J.; Hosseinali, S. H.; Hasan, A.; Kani, P. H.; Talaei, A. J.; Karim, A. Y.; Nanakali, N. M. Q.; Salihi, A.; Aziz, F. M.; Yan, B.; Khan, R. H.; Saboury, A. A.; Falahati, M.; Enzyme immobilization onto the nanomaterials: Application in enzyme stability and prodrug-activated cancer therapy. International Journal of Biological Macromolecules 2020, 143, 665. [CrossRef]

28. Rios, N. S.; Neto, D. M. A.; dos Santos, J. C. S.; Fechine, P. B A.; Fernández-Lafuente, R.; Gonçalves, L. R. B.; Comparison of the immobilization of lipase from Pseudomonas fluorescens on divinylsulfone or $p$-benzoquinone activated support. International Journal of Biological Macromolecules 2019, 134, 936. [CrossRef]

29. Rodrigues, R. C.; Virgen-Ortíz, J. J.; dos Santos, J. C. S.; Berenguer-Murcia, Á.; Alcantara, A. R.; Barbosa, O.; Ortiz, C.; Fernandez-Lafuente, R.; Immobilization of lipases on hydrophobic supports: immobilization mechanism, advantages, problems, and solutions. Biotechnology Advances 2019, 37, 746. [CrossRef]

30. Vitola, G.; Büning, D.; Schumacher, J.; Mazzei, R.; Giorno, L.; Ulbricht, M.; Development of a Novel Immobilization Method by Using Microgels to Keep Enzyme in Hydrated Microenvironment in Porous Hydrophobic Membranes. Macromolecular Bioscience 2017, 17, 1600381. [CrossRef]

31. Nawaz, M. A.; Aman, A.; Rehman, H. U.; Bibi, Z.; Ansari, A.; Islam, Z.; Khan, I. A.; Qader, S. A. U.; Polyacrylamide Gel-Entrapped Maltase: An Excellent Design of Using Maltase in Continuous Industrial Processes Applied Biochemistry and Biotechnology 2016, 179, 383. [CrossRef]

32. Faber, K.; Kroutil, W.; New enzymes for biotransformations. Current Opinion in Chemical Biology 2005, 9, 181. [CrossRef]

33. Qader, S. A. U.; Aman, A.; Azhar, A. Continuous Production of Dextran from Immobilized Cells of Leuconostoc mesenteroides KIBGE HA1 Using Acrylamide as a Support. Indian Journal of Microbiology 2011, 51, 279. [CrossRef]

34. Rehman, H. U.; Aman, A.; Nawaz, M. A.; Karim, A.; Ghani, M.; Baloch, A. H.; Qader, S. A. U.; Immobilization of pectin depolymerising polygalacturonase using different polymers. International Journal of Biological Macromolecules 2016, 82, 127. [CrossRef]

35. Rogério, M. C. P.; Borges, I.; Neiva, J. N. M.; Rodriguez, N. M.; Pimentel, J. C. M.; Martins, G. A.; Ribeiro, T. P.; Costa, J. B.; Santos, S. F.; Carvalho, F. C.; Valor nutritivo do resíduo da indústria processadora de abacaxi (Ananas comosus L.) em dietas para ovinos. 1. Consumo, digestibilidade aparente e balanços energético e nitrogenado. Arquivo Brasileiro de Medicina Veterinária e Zootecnia 2007, 59, 773. [CrossRef]

36. Marques, A. F.; Paulo, R.; Ii, C.; Macedo, M.; Iii, D. O.; Cristiane, M.; Souza, M. De; Ramiton, R.; Monteiro, D. C.; Santos, R.; Vieira, A.; Cleiton, J.; Alvarado, C.; Ix, A.; Enzymatic
Biocatalyst using enzymes from Pineapple (Ananas comosus) Peel Immobilized in Hydrogel Beads. Revista Eletrônica em Gestão, Educação e Tecnologia Ambiental 2019, 23, 32. [CrossRef]

37. Hartree, E. F.; Determination of protein: A modification of the lowry method that gives a linear photometric response. Analytical Biochemistry 1972, 48, 422. [CrossRef]

38.. Pencreac'h, G.; Baratti, J. C.; Hydrolysis of p-nitrophenyl palmitate in n-heptane by the Pseudomonas cepacia lipase: A simple test for the determination of lipase activity in organic media. Enzyme and Microbial Technology 1996, 18, 417. [CrossRef]

39. Kalogeris, E.; Sanakis, Y.; Mamma, D.; Christakopoulos, P.; Kekos, D.; Stamatis, H.; Properties of catechol 1,2-dioxygenase from Pseudomonas putida immobilized in calcium alginate hydrogels. Enzyme and Microbial Technology 2006, 39, 1113. [CrossRef]

40. Machado, L. L.; Lemos, T. L. G.; de Mattos, M. C.; de Oliveira, M. da C. F.; de Gonzalo, G.; Gotor-Fernández, V.; Gotor, V.; Immobilized Manihot esculenta preparation as a novel biocatalyst in the enantioselective acetylation of racemic alcohols. Tetrahedron: Asymmetry 2008, 19, 1419. [CrossRef]

41. Machado, L. L.; Monte, F. J. Q.; de Oliveira, M. da C. F.; de Mattos, M. C.; Lemos, T. L. G.; Gotor-Fernández, V.; de Gonzalo, G.; Gotor, V.; Bioreduction of aromatic aldehydes and ketones by fruits' barks of Passiflora edulis. Journal of Molecular Catalysis B: Enzymatic2008, 54, 130. [CrossRef]

42. Macrae, A. R.; Lipase-catalyzed interesterification of oils and fats. Journal of the American Oil Chemists' Society 1983, 60 , 291. [CrossRef]

43. Zeng, J.; Du, W.; Liu, X.; Liu, D.; Dai, L.; Study on the effect of cultivation parameters and pretreatment on Rhizopus oryzae cell-catalyzed transesterification of vegetable oils for biodiesel production. Journal of Molecular Catalysis B: Enzymatic 2006, 43, 15. [CrossRef]

44. Machado, L. L.; de Gonzalo, G.; Lemos, T. L. G.; de Mattos, M. C.; de Oliveira, M. da C. F.; Gotor-Fernández, V.; Gotor, V.; Enantioselective acetylation of racemic alcohols by Manihot esculenta and Passiflora edulis preparations. Journal of Molecular Catalysis B: Enzymatic 2009, 60, 157. [CrossRef]

45. Machado, L. L.; Souza, J. S. N.; de Mattos, M. C.; Sakata, S. K.; Cordell, G. A.; Lemos, T. L. G.; Bioreduction of aldehydes and ketones using Manihot species. Phytochemistry 2006, 67, 1637. [CrossRef]

46. Belikov, A. V.; Smolyanskaya, O. A.; Protasov, V. A. Em Tuchin, $\mathrm{V}$. V., Measurement of angle-of-rotation of polarization plane in fat tissue in vitro. Optical Technologies in Biophysics and Medicine V 2003, 96. [CrossRef]

47. Fonseca, A. M.; Monte, F. J. Q.; de Oliveira, M. da C. F.; de Mattos, M. C.; Cordell, G. A.; Braz-Filho, R.; Lemos, T. L. G.; Coconut water (Cocos nucifera $\mathrm{L}$.) - $\mathrm{A}$ new biocatalyst system for organic synthesis. Journal of Molecular Catalysis B: Enzymatic 2009, 57, 78. [CrossRef] 
48. Ketnawa, S.; Chaiwut, P.; Rawdkuen, S.; Pineapple wastes: A potential source for bromelain extraction. Food and Bioproducts Processing 2012, 90, 385. [CrossRef]

49. Ganasen, P.; Khan, M. R.; Kalam, M. A.; Mahmud, M. S.; Effect of visible light on catalytic hydrolysis of $p$-nitrophenyl palmitate by the Pseudomonas cepacia lipase immobilized on sol-gel support. Bioprocess and Biosystems Engineering 2014, 37, 2353. [CrossRef]

50. Boudrant, J.; Woodley, J. M.; Fernandez-Lafuente, R.; Parameters necessary to define an immobilized enzyme preparation. Process Biochemistry 2020, 90, 66[CrossRef]

51. Mei, S.; Han, P.; Wu, H.; Shi, J.; Tang, L.; Jiang, Z.; One-pot fabrication of chitin-shellac composite microspheres for efficient enzyme immobilization. Journal of Biotechnology 2018, 266, 1. [CrossRef]

52. Sisila, V.; Puhazhselvan, P.; Aarthy, M.; Sakkeeshyaa, G.; Saravanan, P.; Kamini, N. R.; Ayyadurai, N.; Esterification of Polymeric Carbohydrate Through Congener Cutinase-Like Biocatalyst. Applied Biochemistry and Biotechnology 2021, 193, 19. [CrossRef]
53. Galgali, A.; Gawas, S. D.; Rathod, V. K.; Ultrasound assisted synthesis of citronellol laurate by using Novozym 435. Catalysis Today 2018, 309, 133. [CrossRef]

54. Hossain, M. A.; Mohamed Iqbal, M. A.; Julkapli, N. M.; San Kong, P.; Ching, J. J.; Lee, H. V.; Development of catalyst complexes for upgrading biomass into ester-based biolubricants for automotive applications: a review. RSC Advances 2018, 8, 5559. [CrossRef]

55. Prasertpong, P.; Jaroenkhasemmeesuk, C.; Regalbuto, J. R.; Lipp, J.; Tippayawong, N.; Optimization of process variables for esterification of bio-oil model compounds by a heteropolyacid catalyst. Energy Reports 2020, 6, 1. [CrossRef]

56. Silva, J.; Malta, V.; Santos-Rocha, M.; Almeida, R.; Gomes, M.; Vicente, C.; Barbosa, K.; Enzymatic Hydrolysis, Fermentation And Biofuels Production From Ananas Comosus Crown Química Nova 2018, 2018. [CrossRef]

57. Reis, C.; Sousa, E.; Serpa, J.; Oliveira, R.; Oliveira, R.; Santos J.; Design of immobilized enzyme biocatalysts: drawbacks and opportunities. Qim. Nova 2019, 43, 1. [CrossRef] 